The most surprising feature of the study was the relatively good growth made by the plants over the entire range of pressures used; differences were noted, but in general, all plants developed even at the extremes of pressure. At pressures greater than atmospheric, nitrogen gas was used to increase the total pressure; the growth of the plants appeared to be quite normal and indistinguishable from plants grown in air. At pressures less than atmospheric and greater than $0 \cdot 20 \mathrm{~atm}$, a definite stimulation of plant development was noted. The leaves were larger and broader and the plants were slightly greater in size (dry weight) than the control plants kept at normal pressure.

Pressures below 0.20 atm. usually caused some inhibition of growth, probably due to low pressures of oxygen. Previous studies of the effect of $p \mathrm{O}_{2}$ indicated that plants kept in atmospheres in which the $p \mathrm{O}_{2}$ becomes less than $0.05 \mathrm{~atm}$. develop typical signs of carbohydrate excess, namely, red stems, yellow leaves and stalky growth habit. Root development under these conditions is characterised by tuberisation. Responses similar to these were observed in plants grown under low total pressure and hence low pressure of oxygen.

Occasionally freak growths were encountered in. plants grown under low pressures, including false nodules on the roots, long and pointed leaves and, more rarely, four and five leaves instead of the usual three. Similar studies with other species might be of value in interpretation of types of plant growth at different altitudes.

Herman Frasch Foundation in

P. W. WIISON.

Agricultural Chemistry,

Depts. of Agricultural Bacteriology and Chemistry, University of Wisconsin, Madison, $W$ is. June 28.

2 E. M. Smyth, Science, 80, 294； 1934.

\section{Celluloid Tubes for Sampling Cores of Deep Sea Mud}

IN recent years, there has been considerable progress in obtaining long cores of deep sea mud in the course of oceanographical and limnological work. Analysis of the stratification of these cores frequently gives valuable geological, geochronological and palæoclimatological results. During deep sea investigations it is possible - at least in the U.S.S.R.to secure cores four to five metres in length. The preservation and subsequent examination of these cores present, however, some difficulties, due to the necessity of pushing out the obtained core from the Ekman tube, the Meteor type of sounding tube, and the glass container. This operation is often. followed by the secondary deformation of the core, and includes other difficulties of minor importance.

The use of glass containers permits the cores obtained to be kept for a long time in a humid and undisturbed condition. Recently it has been found practicable to remove the cores from metallic tubes in such containers on board ship (Dr. Kuenen ${ }^{1}$ on board the Willebrord Snellius). This may be ascribed to the fact that the glass container, being placed inside the Ekman or the Meteor type tubes, narrows the opening of such a tube, and consequently the length of core is considerably diminished.
Dr. Kuenen's method, however, causes the deformation to be greater, and even doubled.

Instead of glass containers we have used brass ones, with thin walls, that have been placed in tubes of the Meteor type or simply adjusted to their stopper. They are not transparent, however, and in using them the process of subsequent withdrawing of cores for their further examination is quite unavoidable. Glass containers, in spite of their transparency and non-oxidisability, have necessarily thick walls and are very fragile and heavy.

In connexion with these difficulties, I venture to suggest that celluloid or some other transparent plastic material be used for the preparation of containers to secure deep sea mud. These containers could have very thin walls $(0 \cdot 2-0 \cdot 3 \mathrm{~mm}$. or less) and would possess many following advantages : they would be cheap, light, transparent and chemically inactive ; moreover, the core could be withdrawn by cutting the container along its length. The thin walls of the suggested containers would make it possible to use them inside the Ekman or Meteor type tubes without diminishing the size of the openings. The core included in such a container could be divided into vertical or horizontal sections, even without having to be withdrawn from the container.

\section{State Institute of Hydrology, Leningrad, U.S.S.R. June 21.}

${ }^{1}$ Kuenen, H., Die Viermeter-Lotröhre der Snellius Expedition. Ann. der Hydrogr. u. Marit. Meteorol. H. III, 1932. See also : Stetson, H. C., The Bottom Deposits, Sci. Results of the Nautilus Expedition, 1931. Papers in Phys. Oceanogr., etc., vol. 11, No. 3 P.V. 1933. Camb. Mass.

\section{Symbiotic Association between Flies and Nematodes in Galls of Eucalyptus Trees}

GALLING of the flower buds of certain trees in Australia, notably Eucalyptus rostrata and E. hemiphloia, is sometimes so heavy that no flowers appear, and no honey harvest is reaped. The chief causes of galling are agromyzid flies of the genus Fergusonina, Malloch.

Inside the galls the fly larvæ are associated with small nematodes, which I have placed in a sub-genus of the plant-parasitic genus Anguillulina. The nematodes live in the gall-cavity in contact with the fly larvæ, and ultimately a number of fertilised females enter the body-cavity of the female larvæ of the fly. There eggs are laid, and when the female fly in turn deposits its eggs in young flower buds a number of larval nematodes accompany them. The nematodes at once feed on the plant tissues and give rise to proliferating cells on which the fly larvæ feed, making hollows in which they are associated with the worms.

The symbiosis appears to have arisen as an accidental association between agromyzid leaftunnelling larvæ and plant parasitic nematodes.

Goodey $^{1}$ has described a parasitic association between the frit-fly of oats and a nematode, which may correspond to one of the steps in the evolutionary series which led to the highly organised association outlined above.

Division of Entomology,

Council for Scientific and

Industrial Research,

Canberra, Australia.

${ }^{1}$ Phil. Trans. Roy. Soc., B, 218, 315; 1930. 